\title{
Raising: Dutch Between English and German
}

\author{
Johan van der Auwera \\ University of Antwerp
}

\author{
Dirk Noël \\ The University of Hong Kong
}

\begin{abstract}
As a complement to C. B. van Haeringen's classic comparative study (1956) that positioned the grammar of Dutch in between the grammars of English and German, this study compares the productivity of three kinds of "raising" patterns in these languages: Object-to-Subject, Subject-to-Object, and Subject-to-Subject raising. It establishes the extent to which Dutch, as well as English and German, have evolved from the old West Germanic starting point these languages are assumed to have shared in this area of grammar. The results are a test case for Hawkins' (1986) case syncretism account of the difference in "explicitness" between the grammars of English and German.*
\end{abstract}

\section{Introduction.}

A classic in the contrastive typology of English and German is Hawkins 1986. Its central synchronic hypothesis is that "where the grammars of English and German contrast, the surface forms (morphological and syntactic) of German are in a closer correspondence with their associated meanings" (Hawkins 1986:121). This is coupled with a diachronic hypothesis, explicitly recalling Sapir 1921: the differences between English and German he discusses are all direct or indirect consequences of a case syncretism, which affected English much more than German, so that with respect to their very similar older stages (Old English and Old German), it is English that changed the most. The hypotheses are illustrated with a

\footnotetext{
* Thanks are due to Timothy Colleman, Frans Daems, Freek Van de Velde, and An Van linden for their answers to questions we put to them and/or for their comments on earlier versions of the paper. Van der Auwera's work was supported by the Belgian Federal Grant P6/44 (within the program of interuniversity attraction poles). Noël's work was supported by the University of Hong Kong Seed Funding Programme for Basic Research (\#200611159021).
} 
long list of phenomena, involving morphology and syntax, both clauseinternal and clause-external. Here is a simple illustration: English does not distinguish between dative and accusative, whereas German does. Consequently, English has only one translation, behind the table, for the German directional hinter den Tisch and the static hinter dem Tisch (Hawkins 1986:37). English is, therefore, for Hawkins (1986), synchronically more ambiguous or vague, and since Old English did have the distinction between dative and accusative, English is the diachronically more progressive language.

Hawkins 1986 has received favorable response (for example, Shannon 1987, 1988, Mair 1990), but it has also been criticized (for example, Rohdenburg 1990, 1992, 1998; Mair 1992; Kortmann \& Meyer 1992). Hawkins himself has changed his mind about the nature and ultimate explanation of the underlying unity (Hawkins 1992). To judge from König \& Gast 2007, the most recent contrastive analysis of German and English to date, the following seems clear:

(i) Contrasts such as the ones described in Hawkins 1986 do not, in fact, characterize all sections of the grammar; put in simple terms, sometimes it is English rather than German that has the more explicit grammar.

(ii) For those sections of the grammars discussed in Hawkins 1986 his synchronic claims remain fully valid: Again, in simple terms, for many sections of the grammar, German is indeed more explicit than English.

As König \& Gast (2007) do not focus on diachrony, the question of a single, unifying explanation, ultimately a diachronic one in terms of case syncretism, remains open.

One of the contrasts discussed by Hawkins concerns so-called raising. Hawkins distinguishes three types:

(i) Object-to-Subject raising (O-S RAISING), also known as "tough movement;"

(ii) Subject-to-Object raising (S-O RAISING), also known as "accusativus cum infinitivo" (ACI), "accusative and infinitive", and "Exceptional Case Marking;" 
(iii) Subject-to-Subject raising (S-S RAISING), one subtype of which is known as "nominativus cum infinitivo" (NCI) or "nominative and infinitive."

The subtypes are illustrated in $1-3$. The b-sentences exemplify constructions in which the relevant italicized and tagged subject or object is raised. The a-sentences are constructions with no raising.

(1) O-S raising

a. It is easy to convince $J o h n_{\mathrm{O}}$.

b. John $n_{\mathrm{S}}$ is easy to convince.

(2) S-O raising

a. I believe that $J o h n_{\mathrm{S}}$ is ill.

b. I believe $J o h n_{\mathrm{O}}$ to be ill.

(3) S-S raising

a. It so happened that $J o h n_{\mathrm{S}}$ was ill.

b. John $n_{\mathrm{S}}$ happened to be ill.

In the b-sentences, the raised constituent lacks an obvious semantic relation (or thematic role) vis-à-vis the main clause predicate. Thus, in $1 b$, it is arguably not John who is easy, but the convincing of John. In 2b, the speaker does not believe John, but rather that John is ill. In $3 b$, it is not John that happened but his illness. For the O-S and S-S subtypes, the non-raised versions are impersonal constructions, with a dummy it subject.

Hawkins' synchronic claim is that raising is easier in English than in German. Either German does not manifest the subtype at all, while English does, or both languages exhibit raising, but English has more predicates that permit it than German. Because of the absence of an obvious semantic relation of the raised constituent to the main clause predicate, the syntax of German would reflect the semantics better than the syntax of English. This synchronic claim is coupled with a diachronic one. English and German used to have very similar raising options, and it is English that changed the most. More specifically, both languages used 
to have very limited raising options, and it is only English that expanded significantly this aspect of its grammar (Hawkins 1986:82).

For many aspects of the grammar, Dutch may be said to be in between German and English, a claim defended eloquently in the classic study by Van Haeringen (1956) (see Vismans et al. 2010). One should, therefore, address the question of whether Dutch also occupies such an in-between position with respect to raising and its subtypes, and why this is so, or, as the case may be, why not. This has not yet been done. Van Haeringen (1956) did not do it, which is not surprising for he did not focus on syntax. However, it has not been done by anyone else in the last half-century either, at least not systematically, though there is a substantial body of relevant work, usually focusing on English and Dutch (especially Fischer 1989, 1992, 1994, 1997, 2000, who occasionally also mentions German; Van der Wurff 1990), and perhaps one study on Dutch and German (Jordens \& Rohdenburg 1972). One might have expected that the very appearance of Hawkins' (1986) book, especially at the time, when the author was affiliated with a Max Planck Institute in Dutch speaking Nijmegen, would have led someone to systematically check each of the Hawkins claims for Dutch. This, however, did not happen, nor did the fiftieth anniversary of Van Haeringen 1956 prompt this kind of study. ${ }^{1}$ The aim of this contribution is to fill this gap.

This paper can also be seen as a partial and belated reaction to a remark by Shannon (1988:820) in his review of Hawkins 1986: "It would also be interesting to place the other Germanic languages along the posited continuum." Indeed, a special reason for bringing Dutch into the picture is that it can serve as a test for the hypothesis offered for explaining the differences between English and German. Whatever Dutch raising facts turn out to be in relation to those of English and German, one would expect the following: ${ }^{2}$

\footnotetext{
${ }^{1}$ Hüning et al. 2006, which marks this fiftieth anniversary, does not contain any reference to Hawkins 1986.

${ }^{2}$ Shannon (1988:820) has a different expectation, which is more specific and not at all in the spirit of Van Haeringen 1956. The quote just offered continues with: "Dutch and Afrikaans, for example, have both lost case, but are still remarkably more like G[erman] with respect to almost all of the relevant contrasts." We will see that the raising facts of Dutch do not answer this expectation.
} 
(i) The factor that is hypothesized by Hawkins (1986) to be responsible for the difference between English and German is at work in Dutch as well, if the raising facts of Dutch are similar to those of English.

(ii) This factor is not at work in Dutch, in case the raising facts of Dutch are similar to those of German.

(iii) This factor is only partially at work in Dutch, if the raising facts of Dutch turn out to be "in between" those of English and German.

In what follows, we first set the boundaries of the three raising types mentioned above (section 2) and then compare the productivity of each type in English, German, and Dutch (sections 3-5). Each time we step back in time and look at the older stages of the languages, first and foremost at Old English. It is for this language that the raising facts have been described best, and we assume that the raising facts of Old German and Old Dutch are very similar (compare Hawkins 1986:82 for a claim relative to German and English). In the final section of the paper, we return to Hawkins 1986 to try to account for the degree to which the raising patterns in question are more or less productive in Dutch than in English and German. We also bring in other explanations that have to do with word order (Fischer 1989, 1992, 1994; Mair 1990; Los 2005), constructional semantics (Colleman \& Noël 2009; Noël \& Colleman 2009), and lexical overlap among the predicates that allow different types of raising.

\section{Terminology and Scope of Study.}

For the purposes of this study, we have to make some methodological and notional provisions. First, our use of the term "raising" is theoryneutral. In other words, we do not assume any particular syntactic theory and also no transformation or process, in a synchronic sense, which in some way derives one sentence or structure from another sentence or structure. For example, in 1 above we do not consider 1a to be synchronically basic and $1 \mathrm{~b}$ derived; nor is there a sense, other than a loose or metaphorical one, in which John is lifted ("raised") out of its subordinate clause and "moved" into the main clause. We use "raising" as a convenient cover term for three types of syntactic patterns, distinguishing between O-S, S-O, and S-S raising. For each of the three phenomena, there are two constructions that are close in meaning. However, in one of them, a constituent is construed as the subject or object of a subordinate clause only, while in the other, the same constituent is construed as the 
subject or object of the main clause (independently of whether one would want to maintain that the constituent combines the main clause function with a subordinate clause one).

Furthermore, the term "raising" is short and well known, and it already has a documented use as a descriptive cross-theoretical label (see Comrie \& Matthews 1990; Mair 1992:169, 1993:5; Langacker 1995; Dik 1997:344-351; Hilpert \& Koops 2005). ${ }^{3}$ Our practice is also similar to that followed in Hawkins 1986, for he uses the relatively non-technical framework of the "standard theory" of generative grammar "for descriptive convenience" (p. 9), yet in full awareness that generative grammarians of the early and mid eighties had long moved on to different frameworks.

Second, we only look at constructions that come in pairs, that is, constructions with a raised and a non-raised variant, and where the raised constituent has no semantic (thematic) link to the main clause predicate. Consider first the pair in 4 , in contrast to the $\mathrm{O}-\mathrm{S}$ raising pair in 1.

(4) a. *It is pretty to look at the plants.

b. The plants are pretty to look at.

Arguably, 4b is similar to $1 \mathrm{~b}$. However, since $4 \mathrm{~b}$ lacks a non-raised counterpart it is different from 1b. In the terminology of Hawkins 1986, one could say that easy is an "optional" trigger and pretty is an "obligatory" one. In this study, we only look at optional raising triggers.

Let us now turn to $\mathrm{S}-\mathrm{O}$ raising and consider 5 .

(5) a. I saw that John smiled.

b. I saw John smile.

The sentences in 5 are similar to the S-O raising pair in 2: There are two grammatical constructions (unlike in 4). Moreover, just as John is the subject of to be ill in 2, John is the subject of smile in 5, and just as John can also be considered to be the object of believe, John can be considered to be the object of saw. However, there is one difference: John is also the Theme (or Goal or even Semantic Object) of saw, but not of believe.

\footnotetext{
${ }^{3}$ The term "tough movement" is also used cross-theoretically (for example,
} Mair 1990:58). 
When I saw John smile, I also saw John, but when I believe John to be ill, I do not believe John. Both constructions, $2 \mathrm{~b}$ and $5 \mathrm{~b}$, are sometimes referred to as "accusative and infinitive." However, the former, but not the latter, is sometimes called a "genuine" accusative and infinitive. Here we only consider such genuine constructions. ${ }^{5}$

Finally, there is the contrast between 6 and the S-S raising pair in 3.

(6) a. *It so ceased that John was ill.

b. John ceased to be ill.

John certainly did not cease any more than John happened in 3, but the cease predicate does not permit any non-raised, impersonal construal. Thus, cease could be argued to be an obligatory raiser, but in this study, we only consider optional ones, like happen.

The decision to restrict the study to cases such as $1-3$ and to leave cases such as 4-6 out of the discussion is essentially a strategic one: we want to arrive at a plausible answer to our research question by considering a well-delineated sample of all the data that could possibly be considered. There is no claim that one cannot usefully extend the term "raising" to cases like 4-6. It is also clear that a complete study of raising would address cases like 4-6 and account for the differences between them and 1-3, irrespective of whether the use of the term "raising" is appropriate for 4-6.

Third, we do not discuss the semantic or functional differences between the raised and non-raised construction types; all we say is that they are close in meaning. We do not want to imply that semantic or functional considerations need not be brought in as well in a complete analysis of raising. We believe that the hypotheses adopted here account for differences in the productivity between Dutch, English, and German raising constructions and are fully compatible with, for instance, cognitive grammatical analyses such as Langacker 1995, constructiongrammatical ones such as Hilpert \& Koops 2005, or discourse-pragmatic ones along the lines of Noël 1997, 1998, 2003. Also, even though we

\footnotetext{
${ }^{4}$ For a survey of the conceptual and terminological distinctions in this area of grammar, see Fischer 1989:144-156.

${ }^{5}$ We do not imply, however, that the distinction is always very clear; see Hawkins 1986:82 and earlier Bolinger 1967.
} 
discuss the raising facts from a diachronic perspective, there are many issues left untouched or only barely touched upon, for instance, the role of language contact (in particular, Latin or French), the role of grammaticalization (Noël 2001, 2008), and subjectification (De Haan 2007).

With respect to O-S raising, there are some more restrictions. We limit the study to the use of bare adjectives, such as easy in 1. We do not study the effect, if any, of adding modifiers such as too or enough, yielding too easy or easy enough. We also do not study the extent to which the raised adjective and its infinitive constitute a separate unit (an adjective phrase), which can then occur as a premodifier, as in an-easy-to-take laxative (see Nanni 1978:9) or an easy-to-use dictionary (Mair 1993:14), nor do we consider the occasional O-S raising use of nouns such as $a$ godsend (Mair 1987:60-61) or fun. We only include constructions with copula be and leave out constructions with other predicates such as seem (X seems easy to INF). Also, we do not discuss the role of a pattern with a passive infinitive (as in easy to be convinced), which seems to have been typical for Early Modern English (Fischer 1991:175-179, see also Van linden 2008). The status of for/für/voor phrases (as in something which is easy for her to do) is not looked at either.

Finally, for some adjectives, such as essential, the non-raised pattern allows complementation with a finite clause as well, which has an explicit subject.

(7) a. It is essential to read these books.

b. It is essential that you/one (should) read these books.

c. These books are essential to read.

One could argue that this alternation between non-finite raising and finite non-raising brings $\mathrm{O}-\mathrm{S}$ raising more in line with the other types, for there the finiteness alternation is obligatory. However, with the adjectives that are considered to be the central members of the optional O-S raising adjective category, like easy and tough, the finite complementation pattern is impossible, as shown in 8 below. For this reason, finite patterns such as $7 \mathrm{~b}$ have rarely been addressed in raising studies - Van linden (2008, 2009b) clearly being an exception.

(8) *It is easy that you should convince John. 
We do not focus on the finite complementation pattern either, but we do mention it briefly when we discuss the situation in Old English. Something we do discuss at fairly great length, however, is Dutch O-S raising complementizer choice, that is, te vs. om te.

Finally, we focus on the raising constructions of the three standard languages. For Dutch, we briefly comment on a possible difference between the southern and the northern variant, though, and we make a few notes on nonstandard southern constructions as well. However, these notes remain modest and are not paired with observations about nonstandard German or English. Also, for English, we only discuss British English.

\section{O-S Raising.}

Starting our comparison of the development of raising in Dutch, English, and German with O-S raising, we could refer to a study by DemskeNeumann (1994:77-95) on Old German. Unfortunately, she does not tell us how many adjectives allow the double construal. For Old Dutch, there is no good analysis either (but see Van der Horst 2008:220 for some examples). About Old English we know more, and we propose two groups of adjectives. The a-group concerns ease and difficulty and is based on Fischer et al. 2000:262. ${ }^{6}$ The b-group is based on Van linden (2008, 2009a, 2009b), who uses data from the York-Toronto-Helsinki Parsed Corpus of Old English Prose: these adjectives involve what she calls "goodness" or "fitness" and "necessity."

(9) Old English adjectives allowing O-S raising

a. eaðe(lic) 'easy', leoht 'easy', hefig(tyme) 'hard', earfoð(lic) 'hard', uneaðe 'not easy'

\footnotetext{
${ }^{6}$ Curiously, the O-S expert of the three authors of Fischer et al. 2000 is Van der Wurff, who earlier (Van der Wurff 1990:521) gives a slightly different list, which, though shorter than the one provided in (9) and also covering the domain of ease and difficulty, contains the additional earmlic 'miserable' and lang(sum) 'long' and "possibly some others."
} 
b. behef(e)(lic) 'suitable', bryce 'useful', fremful(lic) 'useful', (ge)cop(lic) 'proper', god 'good', (ge)met(lic) 'fitting', nytweord(e)(lic) 'useful', rihtlic 'right', niedbe(hefe/hof) 'necessary', (nied) pearf (lic) 'necessary'

The adjectives in the b-group typically occur with a non-raised subjunctive finite complement (Van linden 2009b, chapter 4), a pattern which, as mentioned at the end of the previous section, is impossible for the adjectives in the a-group. If the latter group's patterning with infinitival non-raised complements is taken to be the typical alternation with O-S raising, the b-group is consequently marginal for Old English $\mathrm{O}-\mathrm{S}$ raising but not for the later stages of the language. What happens in the course of history is that the b-adjectives begin to "prefer" the infinitival pattern and in this respect align more with the adjectives of ease and difficulty, although finite complementation remains possible too (see the brief discussion of 7b, Van linden 2008, 2009a, 2009b, and the observations on the gradual extension of the class of O-S raising adjectives in Van der Wurff 1990:523 and Fischer 1991:175-179). ${ }^{7}$

7 Another development is the increasingly obligatory presence of a dummy subject in the impersonal non-raised versions (see, for example, Elmer 1991). A hunch, to be verified in further research and so far based on data about the badjectives only (see Van linden 2009b:151-155), is that these adjectives often occur in a construction that can be seen as raising as well as non-raising. Consider the example below, provided to us by Van linden (p.c.):

ðonne he agælð \& forielt ðæt weorc ðe him
when he neglects and puts off the work that him
niedðearf wære to wyrceanne
necessary were to work

'when he neglects and puts off the work which it is necessary for him to do'

It is clear that the constituent $\partial a t$ weorc is relativized, but it is less clear whether it is relativized as the object of wyrceanne or as the (object-to-)subject of ware. The relevance of this idea is the following. First, we have to explain why more and more adjectives would allow O-S raising. Second, change often happens in ambiguous "bridging contexts," in this case, constructions that allow both a raising and a non-raising analysis. Note also that there is evidence from the realm of $\mathrm{S}-\mathrm{O}$ raising, referred to in note 22 below, that relativization eases raising. 
As for the modern languages, English and German are perfect illustrations of the general developmental schema described in Hawkins 1986, that is, modern German still has rather limited O-S raising options, but English has expanded them. Hawkins (1986:78) follows König (1971:88-89), who says that whereas the list of English adjectives allowing O-S raising is very long (see 10 below), in German there are only five adjectives. For both languages, we attempt a subcategorization. The a-group contains adjectives of ease and difficulty, and those in the bgroup are adjectives of positive and negative evaluation. The list in 10 is based on König 1971:88 (where König explicitly states that the list is not exhaustive and could be expanded with participial adjectivals), Mair 1987:60, 1990:59, Nanni 1978:30, and on our own non-systematic observations. We again distinguish two classes.

(10) Modern English adjectives allowing O-S raising

a. easy, simple, convenient, difficult, hard, tough, cumbersome, awkward, tricky

b. interesting, nice, good, fine, desirable, essential, safe, useful, pleasant, pleasurable, instructive, educational, delightful, great, beautiful, excellent, ideal, beneficial, amusing, important, necessary, impossible, odd, strange, weird, bad, painful, boring, tedious, dull, embarrassing, dangerous, risky, expensive, fashionable, depressing, rare, unpleasant, horrible, annoying, loathsome, irritating, illegal

In terms of frequency, the easy/difficult subtypes are very clearly the central (Mair 1987:60), but there is also no doubt that, compared to Old English, the pattern has expanded substantially. Let us now look at the Modern German list in 11.

(11) Modern German adjectives allowing O-S raising

a. leicht 'easy', einfach 'simple', schwer 'hard', schwierig 'difficult'

b. interessant 'interesting'

The list in 11, which is based on König 1971:89, contains the adjectives of ease and difficulty and one additional adjective, namely, interessant. 
Later discussions of the membership of the O-S trigger class go in two directions. First, scholars discuss its exact membership; second, they discuss whether there even is such a category in Modern German. As to the exact membership, assuming that the category itself is real, one can see that König and Gast (2007:210) are a bit more careful, claiming that interessant is "maybe" a member. Earlier, Comrie \& Matthews (1990: 57) had also set interessant apart, considering it colloquial. However, next to the opinion that the exact number is possibly lower than five, there is also the view that it could be slightly higher, with Mair (1994:6) adding unmöglich 'impossible', angenehm 'pleasant', unangenehm 'unpleasant', and wichtig 'important' (and supplying examples as well). Most importantly, though, Mair (1994) does not doubt that the class of $\mathrm{O}-\mathrm{S}$ raisers is very small.

At the same time, it has also been suggested that Modern German might not even have any O-S raisers (any longer), a suggestion found in Comrie \& Matthews 1990:47-50, Brdar \& Brdar Szabó 1992, Mair 1994:5-6, and König \& Gast 2007:6-7, 210. What looks like an O-S raising construction might actually be an extension of the use of a modal be to infinitive. The latter is illustrated in $12 \mathrm{a}$, while $12 \mathrm{~b}$ shows that the modal infinite can be modified by adverbials. The point is then that the construction in $12 \mathrm{c}$ should be thought of as a version of the modal infinitive in $12 \mathrm{a}$ rather than as a raising version of the impersonal construction in $12 \mathrm{~d}$.

(12) a. Dieses Buch ist zu lesen.

this book is to read

'This book can be read.'

b. Dieses Buch ist in der Bibliothek/nur am Samstag zu lessen. this book is in the library only at.the Saturday to read 'This book can be read in the library / only on Saturdays.'

c. Dieses Buch ist leicht zu lesen. this book is easy to read

'This book is easy to read.' 
d. Es ist leicht, dieses Buch zu lesen. it is easy this book to read

'It is easy to read this book.'

Given the similarity of $12 \mathrm{~b}$ and $12 \mathrm{c}$, one can further argue that the form leicht is not an adjective but an adverb. Indeed, in German, an uninflected adjective and a manner adverb can be difficult or even impossible to distinguish. ${ }^{8}$

English is rather different in this respect. First, English does regularly distinguish manner adverbs from adjectives, as in easily and easy. ${ }^{9}$ Second, English no longer has a counterpart to 12a, and even though the English list of O-S triggers is long, English does not allow the clear adverbials which we see in German $12 \mathrm{~b}$, not even with a different word order, as in $13 \mathrm{c} .^{10}$

\footnotetext{
${ }^{8}$ Jordens \& Rohdenburg (1972:115) suggest an intermediate position: the relevant forms would be adjectives that are used in an adverbial way.

${ }^{9}$ However, Old English is a different story. Fischer (1991:157) suggests that the Old English O-S predicates might have to be considered adverbial too.

${ }^{10}$ Older English did allow an adverbial easily, but only with a passive infinitive, as in these examples from the Corpus of Late Modern English Texts (De Smet 2005):
}

(a) The difficulties are not easily to be solved...

(John Dryden, 1692, Discourses on Satire and Epic Poetry)

(b) ...novelties are not now very easily to be found...

(Samuel Johnson, 1759, Rasselas)

(c) These tongues, though they possess many words in common, which is easily to be accounted for by their close proximity, are properly distinct, being widely different in structure.

(George Borrow, 1842, The Bible in Spain)

Visser (2002[1963]:1468) informs us that patterns of the type easily to be done appear for the first time in writing in the last quarter of the sixteenth century, and that they are probably a blend of the types it is easy to be done and it is easily done. He adds that "[t]he number of examples is rather small." The last one he cites dates from 1925. 
(13) a. *This book is to read.

b. *This book is to read in the library / only on Saturday.

c. *This book is in the library/only on Saturday to read.

Of course, for a construction with the "infinitive-like" use of an adverb such as in $12 \mathrm{~b}$ German does not have an impersonal adjectival counterpart, as shown in 14 .

*Es ist in der Bibliothek /nur am Samstag
It is in the library only at.the Saturday
dieses Buch zu lessen.
this book to read

'It is in the library / only on Saturdays to read this book.'

Thus, the question remains whether or not the Modern German alleged or real raising constructions that involve only a handful of adjectives should be seen as instances of modal infinitives extended with adverbs. However, what matters most for our contrastive analysis is that only this small set of adjectives/adverbs allows an impersonal and clearly adjectival construal and hence the contrast with English remains (a point also made by Mair 1994:6). ${ }^{11}$ We also believe that the existence of the modal infinitive and its extendability could even have boosted the real or alleged $\mathrm{O}-\mathrm{S}$ raising pattern, but it did not.

Let us now turn to Dutch. As one is trying to find the Dutch counterparts of the adjectives in the English list, it may seem that Dutch, like English, has also extended the class of O-S triggers (see Jordens \& Rohdenburg 1972:115), but not quite to the same extent. Our proposal for the membership of the present-day Dutch class of O-S triggers is shown in 15 . Once more, we distinguish two classes and, in the absence

\footnotetext{
${ }^{11}$ An anonymous referee pointed out another argument against straightforward O-S raising in German: the occurrence in nonstandard German of apparent O-S raising patterns with nominal infinitives, that is, patterns of the kind das ist leicht zum Verstehen, which do not have matching impersonal patterns either (*Es ist leicht, dieses Buch zum Verstehen). Such patterns do not detract from our contrastive analysis either.
} 
to date of corpus research on the topic, the list is based on personal observation. ${ }^{12}$

\section{Dutch adjectives allowing O-S}

a. (ge)makkelijk 'easy', simpel 'simple', eenvoudig 'simple', moeilijk 'difficult', lastig 'hard'

b. interessant 'interesting', leuk 'nice', goed 'good', fijn 'fine', geweldig 'great', prima 'excellent', uitstekend 'excellent', aangenaam 'pleasant', essentieel 'essential', veilig 'safe', nuttig 'useful', prettig 'pleasant', plezierig 'pleasurable', instructief 'instructive', leerzaam 'educational', aardig 'nice', noodzakelijk 'necessary', belangrijk 'important', onmogelijk 'impossible', pijnlijk 'painful', vervelend 'boring', saai 'dull', irritant 'irritating', duur 'expensive', gevaarlijk 'dangerous', link 'risky', deprimerend 'depressing', vreemd 'strange', raar 'weird'

In 16, we compare the four lists in terms of the numbers of predicates. The numbers are approximations, of course. Old English eaðe and eaðelic represented in 9 as eaðe(lic) counts as one adjective, as does Modern Dutch (ge)makkelijk. We mark each number with the "equal or bigger than" sign, indicating our awareness that we could have easily missed some relevant adjectives. We assume, though we do not really know, that the Old English list characterizes Old West Germanic as a whole. For Modern German, we take the list in 11 plus the four adjectives mentioned by Mair (1994).

\section{Old West Germanic: $\geq 15$}

Modern English: $\geq 52$ Modern Dutch: $\geq 34$ Modern German: $\geq 9$

Interestingly, the claim that what seem to be O-S raising constructions in German should be analyzed as extensions of constructions with modal

\footnotetext{
${ }^{12} \mathrm{We}$ are grateful to an anonymous reviewer for a few additions to the list. Our observations are based on internet searches, and the URLs of the hits suggest that northern Dutch is more tolerant of O-S raising than the southern variety, but this is a matter for further research.
} 
infinitives has been made for modern Dutch as well (Dik 1997:152-154, 346). Furthermore, the observation about adjectives and manner adverbs often being identical also applies. The fact remains, however, that just as in German, the adjectives in 15 allow two construals: an adjectival impersonal construal, and adjectival O-S raising or adverbial and "modal infinitival." Most importantly, Dutch allows many more such constructions than German does. Moreover, the analysis of these constructions, in both German and Dutch, in terms of the extended use of modal infinitives does not explain why the two languages are rather different.

We can now make our first claim on the issue of whether Dutch is in between German and English. The figures in 16 are tentative, but at least with respect to the issue of the intermediacy of Dutch, they leave no doubt. The Van Haeringen hypothesis that Dutch is in between German and English holds ground for O-S raising. English has considerably expanded the set of O-S triggers. Dutch has only done this to a limited extent, while German seems to have shrunk the class (on the assumption, of course, that Old German was like Old English). ${ }^{13}$

However, the story is more complicated. Let us first look at the complementizers used with the O-S triggering adjectives. In English and German, the case is simple: it is always to in English and its counterpart $z u$ in German, in both the raising and non-raising constructions. The direct Dutch counterpart to to and $z u$ is te, and we do indeed find it in the Dutch O-S pairs.

(17) a. Dit boek is moeilijk te verkrijgen.

this book is difficult to get

'This book is difficult to get.'

b. Het is moeilijk dit boek te verkrijgen.

it is difficult this book to get

'It is difficult to get this book.'

\footnotetext{
${ }^{13}$ If Old English eađe(lic) and the like count double, the number for Old West Germanic is higher; then Dutch could be argued to have retained more or less the same number of raising triggers, though the Old English and Modern Dutch classes do not merely consist of cognate adjectives.
} 
For the majority of the adjectives, however, te can only be used under the non-raising construction. The raising construction requires the complex complementizer om te, which is also possible in the non-raising one. ${ }^{14}$

(18) a. *Dit boek is nuttig te lezen.

b. Dit boek is nuttig om te lezen. this book is useful in.order to read 'This book is useful to read.'

c. Het is nuttig dit boek te lezen.

d. Het is nuttig om dit boek te lezen. it is useful in.order this book to read

'It is useful to read this book.'

It turns out, furthermore, that the class of raisers that accept te without om is more or less the same as the one in German. In this respect, Dutch is, therefore, like German. Moreover, om te as such has a direct counterpart in German: um zu.Om te and $u m z u$ are first and foremost purposive complementizers.

(19) a. Ich komme nach Berlin, um zu studieren.

b. Ik kom naar Berlijn om te studeren. I come to Berlin in.order to study

'I come to Berlin in order to study.'

c. *Ich komme nach Berlin, zu studieren.

\footnotetext{
${ }^{14}$ We gloss om (...) te as 'in.order (...) to', because of the prominence of its purposive use. The obligatoriness of om te in $18 \mathrm{~b}$ has been ascribed to the adverbial nature of the predicate by Vliegen (2004:215). Vliegen (2004) does not discuss cases such as $17 \mathrm{a}$, in which om te is not obligatory, but it seems that he would be forced to say that the form nuttig in $18 \mathrm{~b}$ is adverbial, while moeilijk in $17 \mathrm{~b}$ adjectival, for which there might not be independent evidence.
} 
d. *Ik kom naar Berlijn te studeren.

I come to Berlin to study

'I come to Berlin in order to study.'

The English counterpart is in order to, but to is acceptable as well. With respect to this contrast, Fischer $(1997,2000)$ claims that English to is less grammaticalized than either German $z u$ or Dutch te: English has preserved the older purposive meaning better than either Dutch te or German $z u$, and is, therefore, less in need of a "strengthener." ${ }^{15}$ From this point of view, too, Dutch te sides with German $z u$. Note, however, that it is only in Dutch that the complex complementizer is sufficiently bleached to serve O-S raising. Example 20 shows that this is not the case for German um zu, and the interlinear gloss makes it clear that English does not accept the purposive complementizer either.

(20) a. *Es ist leicht, um dieses Buch zu lesen.

it is easy in.order this book to read

'It is easy to read this book.'

b. *Dieses Buch ist leicht um zu lesen. this book is easy in.order to read

'This book is easy to read.'

Thus, with respect to the complex complementizers om te, um zu and in order to, and their use in O-S raising, German and English are alike and Dutch is the special one. What is relevant for the present discussion is that Dutch is not in the middle. In 21, we summarize the grammaticalization differences between the simple and complex complementizers to and in order to, and their counterparts in German and Dutch. Of course, this summary only concerns the facts sketched in 17-20, but it would seem that the claims have a more general validity (see Vliegen 2004 on a

${ }^{15}$ Curiously, earlier English had for to, but it was lost. One could claim, along with Fischer (1997, 2000), that English to had started on the grammaticalization cline, like $z u$ in German and te in Dutch, but then turned back (see also Fitzmaurice 2000). However, this claim does not go uncontested (Los 2005: 229). 
comparison of all the om te / um zu uses of Dutch and German, respectively).

(21) Grammaticalization of the purposive complementizers ${ }^{16}$

a. Dutch te

$$
>\text { English to }
$$

German $z u$

b. Dutch om te >

$$
\text { English in order to }
$$

\section{German $u m z u$}

In what follows, we discuss three more properties of O-S raising and again compare the facts of the three languages. First, Hawkins (1986:78) claims that the object of the O-S construction may be prepositional in English, but not in German. Here Dutch is like English, but it seems that the complementizer has to be the complex om te (an observation already made by Jordens \& Rohdenburg 1972:116, 120).

(22) a. The machine is easy to work with.

b. *Das Gerät ist leicht mit zu arbeiten.

c. De machine is gemakkelijk om mee te werken.

d. *De machine is gemakkelijk mee te werken. the machine is easy in.order with to work

'The machine is easy to work with.'

Second, Hawkins (1986:78; earlier Nanni 1978:8, 1980:571) claims that in English, O-S raising is an "unbounded movement rule." This means, less metaphorically, that in the hierarchy of the clause, the predicates relative to which the raised constituent fulfills the $\mathrm{O}$ and $\mathrm{S}$ roles may be separated by another predicate. In 23a, these two predicates are read and

16 ">" should be read as "grammaticalized more than." 
$b e$, and the intervening predicate is force. In German this is not possible, and neither is it allowed in Dutch.

(23) a. This book is easy for me to force Charles to read.

b. *Dieses Buch is leicht für mich Karl this book is easy for me Charles

$\mathrm{zu}$ lesen zu zwingen

to read to force

c. *Dit boek is gemakkelijk voor mij om Karel this book is easy for me in.order Charles

te dwingen lezen.

to force read

'This book is easy for me to force Charles to read.'

Third, we have already seen that Dutch is unique with respect to complementizer choice. In its southern, essentially Belgian, variety, there is another unique feature. In the raising construction, southern Dutch allows bare $o m$, yet only when the infinitive is bare too.

(24) a. Het boek is gemakkelijk/leuk om lezen. the book is easy/ pleasant to read

'The book is easy/pleasant to read.'

b. *Het boek is gemakkelijk/leuk om in de trein lezen. the book is easy/ pleasant to in the train read 'The book is easy/pleasant to read on the train.'

This pattern is widespread in Belgium and it remains to be seen whether one should consider it standard Southern Dutch or give it nonstandard status. ${ }^{17}$ The bare om probably goes back to a purposive construction too.

\footnotetext{
${ }^{17}$ Frans Daems (p.c.) has drawn our attention to the fact that the language advisers on the relevant page of the governmental organization Taalunie ("Language
} 
In Middle Dutch, the South allowed purposive infinitives not only with bare te but also with bare om - and later also with om te (Duinhoven 1997:196-198; Van der Horst 2008:413-414, 640-641). So, once again, when it comes to the nature of the complementizer, Dutch, this time only its Southern variant, resembles neither German nor English. ${ }^{18}$

\begin{tabular}{|l|l|}
\hline Property of Dutch & Comparison with German and English \\
\hline a. Expansion of O-S raising class & Like English, but not as much \\
\hline b. Little expansion with te & Like German \\
\hline c. Use of om te for purpose & Like German \\
\hline d. Use of om te with O-S raising & Different from German and English \\
\hline e. Object may be prepositional & Like English \\
\hline f. O-S raising is bounded & Like German \\
\hline g. Use of bare om & Different from German and English \\
\hline
\end{tabular}

Table 1. Dutch compared to German and English.

Table 1 summarizes the similarities and differences discussed in this section. ${ }^{19}$ The conclusion is that, in two respects, Dutch is to some extent

Union") withhold judgement, see http://taaladvies.net/taal/advies/vraag/962, accessed on January 22, 2009.

${ }^{18}$ On the more clearly nonstandard level, the South also has voor te 'for to' and van te 'of to' (see Ryckeboer 1983; Gerritsen 1991:58-71) for purpose uses. Timothy Colleman (p.c.) has drawn our attention to the fact that vcor te also allows $\mathrm{O}-\mathrm{S}$ raising uses. Here is an example:

k'Wist niet eens dat de Saturn een dochteronderneming van I-know not even that the Saturn a subsidiary of

Mediamarkt was, da's ook interessant voor te weten Mediamark was that-is also interesting for to know

'I didn't even know that Saturn was a subsidiary of Mediamarkt; that is interesting to know too.'

(http://www.9lives.be/forum/sony-playstation-3/488742-grand-theft-autoiv-52.html, accessed on October 21, 2008)

${ }^{19}$ There is no claim that the comparison is exhaustive (see Wurmbrand 1994). 
in between German and English. On the one hand, the number of triggers lies in between the numbers for German and English. On the other hand, for three properties of O-S raising, Dutch is like German, and for one property it is like English, and if we summarize these four properties we again claim intermediacy. However, claiming intermediate status does not provide a complete picture. There is no sense in which the availability of om te or of om makes Dutch intermediate.

\section{S-O Raising.}

Old English, Old German and, we assume, Old Dutch did not have S-O raising (Hawkins 1986:82), at least not in native texts. It is true that in Latin translations, Old English and Old German had S-O raising structures, but these were calques from Latin (Fischer 1994:94-96; Krickau 1877:12) ${ }^{20}$. Modern German never integrated S-O raising, but in Modern English, S-O raising became very productive. ${ }^{21}$ Hawkins (1986:76-77) refers to Postal 1974:305, 308, where some sixty triggers are mentioned.

${ }^{20}$ Here and elsewhere it is important to realize that work we rely on often uses a wider notion of raising, while our raising often corresponds to what our sources call "optional" raising.

${ }^{21}$ The "dirty bath-water of counter-examples" (Mair 1992:169) does show German to have at least very similar constructions.

(a) Ich glaubte mich betrogen

I believed me deceived

'I believed myself to be deceived.'

(b) Ich glaubte, betrogen worden zu sein.

I believed deceived become to be

'I believed myself to be deceived.'

Nevertheless, they are different constructions (see Hawkins 1986:77). Another point is that German marginally allows S-O raising if the raised constituent is further extracted, that is, relativized, topicalized, or WH-questioned. The example below is an attested one from Mair 1993:11.

was ihr Wasser zu sein meint
what you water to be think
'what you take to be water'

This pattern is possible in Dutch too (see examples in Zajicek 1970:208). Mair (1993) studies this phenomenon in a number of European languages. 
Noël (2001:257-259) checked these in the British National Corpus and found 44 of them attested. In 25 , we list the twenty most frequent S-O triggers found by Noël (2001), in order of decreasing frequency.

(25) consider, believe, find, know, take, show, feel, declare, assume, think, prove, imagine, hold, suppose, judge, reveal, understand, deem, estimate, proclaim

As mentioned already, the origin is generally agreed upon to be a Latinate structure, but in English, the pattern has been fully integrated into the language (see Fischer 1989, 1992). Once again, the Hawkins scenario is clear: Originally, neither German nor English had S-O raising, modern German does not have it either, but in modern English it is very productive. The question is, what happens in Dutch?

It is clear that Dutch is rather like German, but not quite. According to Aarts \& Wekker 1987:313, Dutch has at least some S-O raising. The clearest S-O trigger is probably the verb vinden, literally 'find', but used in the sense 'think' (just like English find). This raising pattern uses a bare infinitive, however. ${ }^{22}$

(26) a. Ik vind dat dit niet kan.

I find that this not can

'I find that this is impossible.'

b. Ik vind dit niet kunnen.

I find this not can.INF

'I find this to be impossible.'

In archaic language, we find a few more verbs, such as achten 'consider', this time with the expected te infinitive (example 27 is from Zajicek

\footnotetext{
${ }^{22}$ Duinhoven (1997:427) does not agree that the raising pattern with vinden is a genuine one, arguing that the subject of the infinitive has a "vague object function" with relation to the matrix verb, and that the pattern is therefore more like the one with perception verbs illustrated in $5 \mathrm{~b}$. In our opinion, such an analysis may point to the historical roots of this 'think' use of vinden, but it no longer applies to its present-day use.
} 
1970:203). The present archaicness is compatible with the hypothesis advanced by Fischer (1994:112-114) that S-O raising with te was more common earlier, in written learned registers, probably also due to Latin influence. It is also compatible with the corpus findings in Noël \& Colleman 2010, which showed that S-O raising was fairly frequent in seventeenth- and eighteenth-century Dutch, especially with oordelen 'judge', zeggen 'say', and bevinden 'find', but virtually disappeared by the beginning of the twentieth century.

Het aantal zwakzinnigen in ons land the number mentally.challenged in our country acht men tussen de 150.000 en de 300.000 te liggen. considers one between the 150,000 and the 300,000 to lie

'One considers the number of mentally challenged persons in our country to lie between 150,000 and 300,000 .'

We can conclude that with respect to S-O raising, Dutch is in between English and German. In this case, however, it is very close to German. This intermediacy is rather different from the one found for O-S raising, which was very complex and only partial. ${ }^{23}$

\section{S-S Raising.}

The older West Germanic languages did not manifest S-S raising (Hawkins 1986:82), and Modern German still does not have it. ${ }^{24}$ Modern English, however, has many triggers, which fall into three classes. The predicates of the first class concern the speaker's uncertainty-König \& Gast (2007:207-211) refer to them as "modal." This class could be further divided into verbal and adjectival raisers. The second class concerns the contingency or actuality of a state of affairs. The third class concerns what is often considered to be the passive construal of S-O

${ }^{23}$ In the Flemish dialects, S-O raising is somewhat more productive, see Taeldeman 1986 and Colleman 2007.

${ }^{24}$ Scheinen was listed in König 1971:68 and Jordens \& Rohdenburg 1972:117, but we follow Ebert (1975) and Hawkins (1986:76) in disqualifying it because the raised constituent need not be a main clause subject. 
raising. Noël (2008) refers to them as "nominative and infinitive," or "NCI" patterns, while König \& Gast (2007:207-211) call them "reportive." ${ }^{25}$ The first two classes have limited membership. The listing in $28 \mathrm{a}, \mathrm{b}$ is, therefore, exhaustive. NCI raising, however, is a productive pattern. In his study of the NCI in the British National Corpus, Noël (2008:328) lists no fewer than 112 predicates, of which 28c lists the top twenty.

(28) English S-S raising

a. appear, look, seem, (be) likely, (be) sure, (be) certain

b. happen, turn out

c. (be) expected, (be) said, (be) supposed, (be) thought, (be) found, (be) seen, (be) known, (be) believed, (be) reported, (be) shown, (be) considered, (be) held, (be) deemed, (be) assumed, (be) taken, (be) estimated, (be) claimed, (be) understood, (be) alleged, (be) felt

The subtypes are illustrated in 29-33. For the first type, we offer examples with verbs and adjectives. For the NCI type, we offer one example with a high frequency verb and one with a low frequency verb.

(29) a. It seems that John is ill.

b. John seems to be ill.

(30) a. It is sure that John is ill.

b. John is sure to be ill.

\footnotetext{
${ }^{25}$ This term is too narrow. As can be seen in $28 \mathrm{c}$, not only do we get utterance verbs, but also cognition and perception verbs. They can all be used evidentially. Two of them, (be) expected and (be) supposed, also appear in deontic constructions. An anonymous reviewer suggested that be meant is also deontic, but mean is a control predicate, not a raising predicate. For example, You're meant to use your intelligence is related to I/They mean you to use your intelligence, and bears no relation to It is meant that you use your intelligence.
} 
(31) a. It turns out that John is ill.

b. John turns out to be ill.

(32) a. It is said that authorities are limited.

b. Authorities are said to be limited.

(adapted from Noël 2008:317, example 9)

(33) a. It is whispered that Smith's job is on the line.

b. Smith's job is whispered to be on the line.

(adapted from Noël 2008:335, example 39)

The contrast between German and English is again striking: The older languages did not allow S-S raising, German still does not allow it, but in English, it is very productive.

As for Modern Dutch, it has two of the three types found in English. For the seem type, Dutch only has verbs (and no adjectives), but then it actually has more verbs than English. The second type is not attested. The NCI is attested, but only with three verbs (Noël \& Colleman 2009).

(34) Dutch S-S raising

a. blijken 'seem', lijken 'seem', schijnen 'seem/be said to', dunken 'seem to someone', heten 'be said to' ${ }^{26}$, toeschijnen 'seem to someone', voorkomen 'seem to someone'

b. geacht worden 'be supposed', verondersteld worden 'be supposed', verwacht worden 'be expected'

Examples 35 and 36 illustrate these uses.

(35) a. Het blijkt dat de pil helpt bij dat soort pijnen. It seems that the pill helps at that sort pains

'It seems that the pill helps with these sorts of pains.'

\footnotetext{
${ }^{26}$ Note that this meaning is reportive. In English, reportives go into the NCI group, but the Dutch NCI does not have any reportive verbs at all (or not any more; see below).
} 
b. De pil blijkt te helpen bij dat soort pijnen. the pill seems to help at that sort pains 'The pill seems to help with these sorts of pains.'

(36) a. Er werd nu verondersteld dat kennis kan groeien. there became now assume that knowledge can grow

'Now it was assumed that knowledge can grow.'

b. Kennis werd nu verondersteld te kunnen groeien. knowledge became now assumed to can.IN grow

'Knowledge was now assumed to be able to grow.'

As was the case for S-O raising (ACI raising), the NCI subtype of S$S$ raising used to be more productive in Dutch than it is today, with a frequency peak in the eighteenth century (Noël \& Colleman 2009:171172). Especially gezegd worden 'be said' was still used in the nineteenth century as an evidential construction similar to English be said, but subsequently the pattern disappeared (Colleman \& Noël 2009). With respect to S-S raising, it is clear again that Dutch is in between English and German, but not quite as close to German as it is for S-O raising. Especially for the NCI subtype, the difference with English is enormous.

\section{On the Intermediate Nature of Dutch Raising.}

We can conclude that, overall, Dutch is intermediate between German and English. In English, raising is very productive; in German, it is either not allowed at all or is very limited, while Dutch is in between. From a diachronic perspective, compared to old Continental West Germanic, English has changed the most, Dutch less, and German least. However, the intermediacy of Dutch is different in each of three cases. For S-O raising, Dutch is very much like German: Dutch is only marginally more tolerant of this pattern. For the two other types, O-S and S-S raising, Dutch is between English and German, although it is difficult to say for which of these types Dutch is more like English. Both types are unique mixes, and with respect to one of the features of O-S raising, namely, the variation between om te, bare te, and bare om, Dutch is not intermediate between German and English but rather has its own unique properties. 
The explanation for the differences between German and English raising offered by Hawkins (1986) (without distinguishing between the subtypes) is ultimately diachronic (see also Shannon 1987:91, 97). In English, nouns and pronouns lost morphological case distinctions. As a consequence, subjects and objects became semantically more diverse and more flexible with respect to their positioning outside the clause in which they are assigned a semantic role (Hawkins 1986:82-83). These two changes are claimed to manifest themselves in various domains of the grammar and raising is one such domain: a raised subject or object is semantically unusual precisely because its semantic role connects it to the predicate of a subclause.

From this point of view, the facts of Dutch are relevant. With respect to case morphology, Dutch nouns and pronouns are like the English ones. One would, therefore, expect greater semantic variation and greater word order freedom of subject and objects in Dutch as well, and that these properties would manifest themselves either in the same way as they do in English or in a way that could be recognized as a stage of progression toward the "English-like" grammar. To check whether this is true, one would have to compare all of the relevant domains of grammar of the three languages, not just the domain of raising, and this is a task that vastly surpasses the goals of this article. However, at least with respect to raising, we can draw two conclusions. On the one hand, Dutch raising is not like English raising. Thus, the decline of case morphology cannot, on its own, be held responsible for the raising differences between German and English (compare also Mair 1992). ${ }^{27}$ On the other hand, the very fact that much of Dutch raising is intermediate between German raising and English raising could indeed reflect the fact that in Dutch, this phenomenon is changing toward the English-type raising,

${ }^{27}$ Mair (1992) compares the presence vs. absence of S-raising and related constructions in Latin, English, French, Spanish, Italian, German, and Russian and strongly disagrees with Hawkins' (1986) view on the relevance of case syncretism. Because this view is based only on two languages, Hawkins' generalization is considered hasty (Mair 1992:175). However, Mair does not take into account that Hawkins's generalization was never meant to apply to Latin, Romance and Russian, but only to German and English, the reason being that these are two languages that were once very similar and that only one of them significantly reduced nominal inflections. For this very reason, Hawkins' generalization should apply to Dutch. 
which means that the decline of case morphology may be at least one of the factors explaining the different raising facts of the three languages.

In his explanatory attempts, Hawkins (1986) does not make a distinction between the three types, a distinction that a complete analysis should take into account. At least for S-O raising, the literature contains an interesting suggestion. In studies on S-O raising that compare Dutch and English, even if only implicitly (for example, Mair (1990:225) compares English with "the historically related Germanic languages"), the fact that English is fond of raising and Dutch is not has been related to the difference in clause-internal word order. The proposal comes in three versions. First, according to Fischer $(1989,1992,1994)$, it was crucial that English turned from OV to VO, unlike Dutch. Second, Los (2005:256-274) argues that it was the loss of "verb second" in English that was essential, that is, the disappearance of the need to have a finite verb or auxiliary in second position. Third, Mair (1990:226) attributes the productivity of S-O raising in English to the overall increased rigidity of word order.

There are two comments to be made about these proposals. First, they fully conform to Hawkins' general hypothesis, for in each case the word order change in English is argued to follow from case syncretism. Second, and more importantly with respect to Dutch as a testing ground for explanations of differences between English and German, for each of the three word order differences Dutch clearly sides with German. Thus, if the degree to which $\mathrm{S}-\mathrm{O}$ raising is productive is indeed related to clause-internal word order regularities, one would expect Dutch and German to be very similar. This is not too far from the truth: German does not have S-O raising at all, and in Dutch it is very marginal. ${ }^{28}$ However, the fact that two languages (Dutch and German) differ from a third one (English) with respect to two properties (clause-internal word order and S-O raising) is in itself not sufficient for positing a causal link.

Let us turn to O-S and S-S raising and offer some speculations. Note that nobody has proposed a link between clause-internal word order and the presence of either O-S or S-S raising. The Dutch facts show that such

\footnotetext{
${ }^{28} \mathrm{We}$ have also seen that $\mathrm{S}-\mathrm{O}$ raising was more frequent in earlier formal registers of Dutch. This is not a problem: S-O raising started as a Latinism, and it was only in English, as Fischer (1994) argues, that the word order facilitated the integration of the pattern.
} 
a link is either absent or not very strong: if similarities in clause-internal word order were to imply similarities in $\mathrm{O}-\mathrm{S}$ and $\mathrm{S}-\mathrm{S}$ raising, Dutch and German should be similar with respect to these kinds of raising, but they are not. This does not have to mean that word order is fully irrelevant, however. If it does play a role, it could prevent Dutch raising from becoming much more productive than German raising. If, on the other hand, Hawkins' (1986) insistence on the explanatory role of case syncretism and its consequences on the semantic variation and clause-external word order of subjects and objects is appropriate as well, then we would expect a greater similarity between Dutch and English raising. Having one factor pulling Dutch toward German and less raising and another pulling Dutch toward English and more raising could in fact result in a situation of Dutch having an intermediate position with ensuing intermediate raising and at least for $\mathrm{O}-\mathrm{S}$ and $\mathrm{S}-\mathrm{S}$ raising such an intermediate position is not in dispute.

It is undoubtedly the case, however, that differences in the productivity of comparable patterns in different languages can be attributed to historical accidents that allowed certain patterns to develop a special functionality in one language, but not in another. English, for instance, has a highly productive evidential NCI S-S construction (such as be said) as well as a non-productive deontic NCI S-S construction (be supposed and be expected). In contrast, the Dutch NCI S-S pattern is not productive (restricted to three verbs, see $34 \mathrm{~b}$ ) and predominantly instantiates a deontic construction, probably because there was less of a functional niche for an evidential NCI S-S construction in Dutch (Colleman \& Noël 2009; Noël \& Colleman 2009). Such considerations fall outside the scope of this contribution, however.

Furthermore, even though the NCI S-S construction should not be reduced to the passive of the S-O (ACI) construction (Noël 2008; Noël \& Colleman 2009), the two constructions are undoubtedly related. First, the two top 20 sets of S-O triggers and NCI S-S triggers in 25 and $28 \mathrm{c}$ display an overlap of 14 verbs. Second, we have mentioned that Dutch shows a decline for both S-O and NCI S-S raising. Given their relatedness, the productivity of either of these patterns may have boosted that of the other (in English), or the lack of productivity of one pattern 
may have knocked the other pattern (in Dutch and German). ${ }^{29}$ This shows that a complete account would have to relate the three domains of raising not only to other domains of grammar, but also to one another.

\section{REFERENCES}

Aarts, Flor G. A. M, \& Herman Chr. Wekker. 1987. A contrastive grammar of English and Dutch. [Contrastieve grammatica Engels/Nederlands.] Leiden: Martinus Nijhoff.

Bolinger, Dwight. 1967. Apparent constituents in surface structure. Word 23. 47-56.

Brdar, Mario, \& Rita Brdar Szabó. 1992. How tough is tough-movement to typologize. New departures in contrastive linguistics. Neue Ansätze in der kontrastiven Linguistik, ed. by Christian Mair \& Manfred Markus, 105-114. Innsbruck: Institut für Anglistik.

Colleman, Timothy. 2007 Ik zie hem morgen (te) komen: Een "echte" accusativus-cum-infinitivo met zien. Taal en Tongval 59. 3-29.

Colleman, Timothy, \& Dirk Noël. 2009. Gezegd worden + te-infinitief: een verouderde evidentiële constructie. Tijdschrift voor Nederlandse Taal en Letterkunde 125.385-403.

Comrie, Bernard, \& Stephen Matthews. 1990. Prolegomena to a typology of tough movement. Studies in typology and diachrony: Papers presented to Joseph H. Greenberg on his 75th birthday, ed. by William Croft, Keith Denning, \& Suzanne Kemmer, 43-58. Amsterdam: Benjamins.

De Smet, Hendrik. 2005. A corpus of Late Modern English texts. ICAME Journal 29. 69-82.

Demske-Neumann, Ulrike. 1994. Modales Passiv und Tough Movement. Tübingen: Max Niemeyer.

Dik, Simon C. 1997. The theory of functional grammar, Part 2: Complex and derived constructions. Berlin: Mouton de Gruyter.

Duinhoven, Anton M. 1997. Middelnederlandse syntaxis: Synchroon en diachroon. 2. De werkwoordgroep. Groningen: Martinus Nijhoff.

Ebert, Robert Peter. 1975. Subject raising, the clause squish, and German scheinen-constructions. Papers from the Eleventh Regional Meeting of the Chicago Linguistic Society, ed. by Robin E. Grossman, L. James San, \& Timothy J. Vance, 177-187. Chicago: Chicago Linguistic Society.

${ }^{29}$ On the functional complementarity of S-O raising and NCI S-S raising constructions in English, see Noël 1998. 
Elmer, Willy. 1981. Diachronic grammar: The history of Old and Middle English subjectless constructions. Tübingen: Niemeyer.

Fischer, Olga. 1989. The origin and spread of the accusative and infinitive construction in English. Folia Linguistica Historica 8. 143-217.

Fischer, Olga. 1991. The rise of the passive infinitive in English. Historical English syntax, ed. by Dieter Kastovsky, 141-188. Berlin: Mouton de Gruyter.

Fischer, Olga. 1992. Syntactic change and borrowing: The case of the accusative and infinitive construction in English. Internal and external factors in syntactic change, ed. by Dieter Stein \& Marinel Gerritsen, 77-88. Berlin: Mouton de Gruyter.

Fischer, Olga. 1994. The fortunes of the Latin-type accusative and infinitive construction in Dutch and English compared. Language change and language structure in a comparative perspective, ed. by Toril Swan, Endre Mørck, \& Olaf Jansen Westvik, 91-133. Berlin: Mouton de Gruyter.

Fischer, Olga. 1997. The grammaticalisation of infinitival to in English compared with German and Dutch. Language history and linguistic modeling: A Festschrift for Jacek Fisiak on his 60th birthday, vol. 1: Language history, ed. by Raymond Hickey \& Stanisław Puppel, 265-280. Berlin: Mouton de Gruyter.

Fischer, Olga. 2000. Grammaticalisation: unidirectional, non-reversable? The case of to before the infinitive in English. Pathways of change: grammaticallization in English, ed. by Olga Fischer, Anette Rosenbach, \& Dieter Stein, 149-169. Amsterdam: Benjamins.

Fischer, Olga, Ans van Kemenade, Willem Koopman, \& Wim Van der Wurff. 2000. The syntax of early English. Cambridge: Cambridge University Press.

Fitzmaurice, Susan. 2000. Remarks on the de-grammaticalisation of infinitival to in present-day American English. Pathways of change: Grammaticalization in English, ed. by Olga Fischer, Anette Rosenbach, \& Dieter Stein, 171-186. Amsterdam: Benjamins.

Gerritsen, Marinel (ed.). 1991. Atlas van de Nederlandse Dialectsyntaxis (AND). Deel I. Amsterdam: Meertens-Instituut.

Haan, Ferdinand de. 2007. Raising as grammaticalization: The case of Germanic SEEM-verbs. Rivista de Linguistica 19. 129-150.

Hawkins, John A. 1986. A comparative typology of English and German: Unifying the contrasts. London: Croom Helm.

Hawkins, John A. 1992. A performance approach to English/German contrasts. New Departures in contrastive linguistics. (Neue Aufsätze in der kontrastiven Linguistik.) Proceedings of the conference held at the Leopold-FranzensUniversity of Innsbruck, Austria, 10-12 May 1991, ed. by Christian Mair \& Manfred Markus, 115-136. Innsbruck: Institut für Anglistik. 
Hilpert, Martin, \& Chris Koops. 2005. A constructional approach to Object-toSubject Raising. Manuscript. Freiburg: University of Freiburg.

Hüning, Matthias, Ulrike Vogl, Ton van der Wouden, \& Arie Verhagen (eds.). 2006. Nederlands tussen Duits en Engels: Handelingen van de workshop op 30 september en 1 oktober aan de Freie Universität Berlin. Leiden: Stichting Neerlandistiek Leiden.

Jordens, Peter, \& Günter Rohdenburg. 1972. Sekundäre Subjektivierungen des Niederländischen und Deutschen in Aktivsätzen. Reader zur kontrastiven Linguistik, ed. by Gerhard Nickel, 106-121. Frankfurt: Athenäum Fischer.

König, Ekkehard. 1971. Adjectival constructions in English and German: A contrastive analysis. Heidelberg: Julius Groos.

König, Ekkerhard, \& Volker Gast. 2007. Understanding English-German contrasts. Berlin: Erich Schmidt.

Kortmann, Bernd, \& Paul Georg Meyer. 1992. Is English grammar more explicit than German grammar, after all? New departures in contrastive linguistics. (Neue Aufsätze in der kontrastiven Linguistik.) Proceedings of the conference held at the Leopold-Franzens-University of Innsbruck, Austria, 10-12 May 1991, ed. by Christian Mair \& Manfred Markus, 155-166. Innsbruck: Institut für Anglistik.

Krickau, Carl. 1877. Der Accusativ mit dem Infinitiv in der englischen Sprache, besonders im Zeitalter der Elisabeth. Göttingen: W. Fr. Kaestner. (InauguralDissertation zur Erlangung der philosophischen Doctorwürde an der GeorgAugust-Universität zu Göttingen.)

Langacker, Ronald W. 1995. Raising and transparency. Language 71. 1-62.

Los, Bettelou. 2005. The rise of the to-infinitive. Oxford: Oxford University Press.

Mair, Christian. 1987. Tough-movement in present-day English. Studia Linguistica 41.59-71.

Mair, Christian. 1990. Infinitival complement clauses in English. Cambridge: Cambridge University Press.

Mair, Christian. 1992. "Raising" in English and German: Formal explanation, functional explanation, or no explanation at all? New departures in contrastive linguistics. (Neue Aufsätze in der kontrastiven Linguistik.) Proceedings of the conference held at the Leopold-Franzens-University of Innsbruck, Austria, 10-12 May 1991, ed. by Christian Mair \& Manfred Markus, 167-176. Innsbruck: Institut für Anglistik.

Mair, Christian. 1993. A crosslinguistic functional constraint on believe-type raising in English and selected European languages. Papers and Studies in Contrastive Linguistics 28. 5-19.

Mair, Christian. 1994. Crosslinguistic semantic motivation for the use of a grammatical construction in English and German: $\mathrm{X}$ is impossible to do/X ist 
unmöglich zu schaffen. Papers and Studies in Contrastive Linguistics 29. 515.

Mair, Christian, \& Manfred Markus (eds.). 1992. New departures in contrastive linguistics. (Neue Aufsätze in der kontrastiven Linguistik.) Proceedings of the conference held at the Leopold-Franzens-University of Innsbruck, Austria, 10-12 May 1991. Innsbruck: Institut für Anglistik.

Nanni, Deborah L. 1978. The easy class of adjectives in English. Amherst, MA: University of Massachusetts at Amherst dissertation.

Nanni, Deborah L. 1980. On the surface syntax of constructions with easy-type adjectives. Language 56. 568-581.

Noël, Dirk. 1997. The choice between infinitives and that-clauses after believe. English Language and Linguistics 1.271-284.

Noël, Dirk. 1998. Infinitival copular complement clauses in English: Explaining the predominance of passive matrix verbs. Linguistics 36. 1047-1065.

Noël, Dirk. 2001. The passive matrices of English infinitival complement clauses: Evidentials on the road to auxiliarihood. Studies in Language 25. 255-296.

Noël, Dirk. 2003. Is there semantics in all syntax? The case of accusative and infinitive constructions vs. that-clauses. Determinants of grammatical variation in English, ed. by Günter Rohdenburg \& Britta Mondorf, 347-377. Berlin: Mouton de Gruyter.

Noël, Dirk. 2008. The nominative and infinitive in Late Modern English: A diachronic constructionist approach. Journal of English Linguistics 36. 314340.

Noël, Dirk, \& Timothy Colleman. 2009. The nominative and infinitive in English and Dutch: an exercise in contrastive diachronic construction grammar. Languages in Contrast 9. 143-180.

Noël, Dirk, \& Timothy Colleman. 2010. Believe-type raising-to-object and raising-to-subject verbs in English and Dutch: A contrastive investigation in diachronic construction grammar. International Journal of Corpus Linguistics 15. 157-182.

Postal, Paul M. 1974. On raising. Cambridge, Mass: MIT Press.

Rohdenburg, Günter. 1990. Aspekte einer vergleichenden Typologie des Englischen und Deutschen: Kritische Bemerkungen zu einem Buch von John A. Hawkins. Kontrastive Linguistik, ed. Claus Gnutzmann, 133-152. Frankfurt: Lang.

Rohdenburg, Günter. 1992. Bemerkungen zu infiniten Konstruktionen im Englishen und Deutschen. New Departures in contrastive linguistics. Neue Aufsätze in der kontrastiven Linguistik. Proceedings of the confernce held at the Leopold-Franzens-University of Innsbruck, Austria, 10-12 May 1991, ed. by Christian Mair \& Manfred Markus, 187-207. Innsbruck: Institut für Anglistik. 
Rohdenburg, Günter. 1998. Subordinate clauses introduced by interpretative verbs in English and their explicit counterparts in German. Kontrast und Äquivalenz: Beiträge zu Sprachvergleich und Übersetzung, ed. by Wolfgang Börner \& Klaus Vogel, 233-249. Tübingen: Gunter Narr.

Ryckeboer, Hugo. 1983. Voor te + infinitief: Verkenning van de dynamiek van een dialectisme. Taal en Tongval 35.83-90.

Sapir, Edward. 1921. Language: An introduction to the study of speech. New York: Harcourt Brace.

Shannon, Thomas F. 1987. Aspects of complementation and control in modern German: The syntax and semantics of permissive verbs. Göppingen: Alfred Kümmerle.

Shannon, Thomas F. 1988. Review of John A. Hawkins, A comparative typology of English and German. Language 64. 820-821.

Taeldeman, Johan. 1986. Nog een beetje te: "Ik zie hem vandaag nog (te) komen." Taal en Tongval 38. 79-82.

Van der Horst, J.M. 2008. Geschiedenis van de Nederlandse syntaxis. Leuven: Universitaire Pers.

Van der Wurff, Wim. 1990. The easy to please construction in Old and Middle English. Papers from the fifth international conference on English historical linguistics, ed. by Sylvia Adamson, Vivien Law, Nigel Vincent, \& Susan Wright, 519-536. Amsterdam: Benjamins.

Van Haeringen, C. B. 1956. Nederlands tussen Duits en Engels. Den Haag: Servire.

Van linden, An. 2008. Activity-oriented and characteristic-oriented constructions: The distribution of voice in the history of the post-adjectival infinitive. English Text Construction 1.239-266.

Van linden, An. 2009a. The rise of the to-infinitive: Evidence from adjectival complementation. English Language and Linguistics 14. 19-51.

Van linden, An. 2009b. Dynamic, deontic, and evaluative adjectives and their clausal complement patterns: A synchronic-diachronic account. Leuven: Catholic University doctoral dissertation.

Vismans, Roel, Matthias Hüning, \& Fred Weerman (eds.). 2010. Dutch between English and German. Journal of Germanic Linguistics (Special Issue) 22.4.

Visser, F. Th. 2002[1963] An historical syntax of the English language, Part three, first half: Syntactical units with two verbs. Leiden: Brill.

Vliegen, Maurice. 2004. Die om te-Konstruktion im Niederländischen und die um zu-Konstruktion im Deutschen: Ein Vorschlag zur Bedeutungsbeschreibung. Leuvense Bijdragen 93. 179-220.

Wurmbrand, Susanne. 1994. The German leicht-construction. Wiener Linguistische Gazette 48-50.87-100.

Zajicek, Jacques. 1970. Réflexions sur l'accusativus cum infinitivo. De Nieuwe Taalgids 63. 198-208. 
Johan van der Auwera

Center for Grammar, Cognition, and Typology

University of Antwerp

Prinsstraat 13

B-2000 Antwerpen

Belgium

[johan.vanderauwera@ua.ac.be]

Dirk Noël

School of English

The University of Hong Kong

Pokfulam Road

Hong Kong S.A.R.

P. R. China

[dnoel@hku.hk] 